\title{
European Shareholder Rights Directive proposals: a critical analysis in mapping with the UK Stewardship Code?
}

\author{
Iris H.-Y. Chiu ${ }^{1}$
}

Published online: 9 June 2016

(C) The Author(s) 2016. This article is published with open access at Springerlink.com

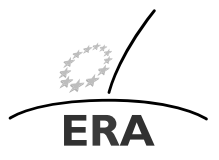

EUROPÄISCHE RECHTSAKADEMIE ACADEMY OF EUROPEAN LAW ACADEMIE DE DROIT EUROPEEN ACCADEMIA DI DIRITTO EUROPEO TRIER - TREVES - TREVIRI

\begin{abstract}
The proposed amendments to the EU Shareholders' Rights Directive purport to improve shareholder rights and powers in investee companies. In general, these initiatives provide minority shareholders with confidence in corporate governance and could be useful as a supply-side stimulating measure to encourage investor interest in pan-European equity markets, therefore contributing to the much-needed European initiative to develop deep and liquid capital markets in order to provide corporate finance. (For example, the EU Capital Markets Union initiative.) This paper focuses on the Articles that purport to develop 'shareholder stewardship' on the part of institutional shareholders. The Articles seem to be derived from the UK Stewardship Code, which legitimises and encourages active corporate governance roles for shareholders, therefore boosting their corporate governance rights. However, this paper critically questions that apparent resemblance, and argues that the Articles borrow the cloak of the stewardship concept to introduce regulatory measures for investment management practice, and the purpose and function of these Articles may not accord with the essential 'corporate governance' paradigm that Directive is framed in.
\end{abstract}

Keywords Stewardship Code $\cdot$ Shareholder Rights Directive $\cdot$ Shareholder activism $\cdot$ Shareholder engagement $\cdot$ Investment management $\cdot$ Corporate governance

Dr. I.H.-Y. Chiu, Reader in Laws

hse-yu.chiu@ucl.ac.uk

1 University College London, Bentham House, Endsleigh Gardens, London WC1H 0EG, UK 


\section{Introduction}

The proposed amendments to the EU Shareholders' Rights Directive ${ }^{1}$ purport to improve shareholder rights and powers in investee companies. In general, these initiatives provide minority shareholders with confidence in corporate governance and could be useful as a supply-side stimulating measure to encourage investor interest in pan-European equity markets, therefore contributing to the much-needed European initiative to develop deep and liquid capital markets in order to provide corporate finance. European companies rely excessively on bank-based finance, and slow economic recovery in the EU after the global financial crisis is seen to be a result of the lack of varied avenues of corporate finance, culminating in a funding lacuna if banks tighten their balance sheets in response to more stringent post-crisis prudential regulation. ${ }^{2}$

This paper focuses on the Articles that purport to develop 'shareholder stewardship' on the part of institutional shareholders. On the face of it, these Articles appear to be derived from the UK Stewardship Code. Hence, one may be under the impression that the Articles serve the same purpose of legitimating and encouraging active behaviour on the part of institutions, therefore according them with more powers in corporate governance. From the agency theory point of view of the corporation, such powers for shareholders improve monitoring of the Board and thus benefit shareholders by checking on divergent interests that directors may pursue. From a resourcebased theory point of view, shareholder activism may even be a useful channel of strategic and risk management monitoring that provides useful feedback to the Board for future decision-making.

This paper, however, argues that the resemblance with the UK Stewardship Code is only apparent. The Directive's measures have a different tenor from the empowering language in the Code and tend towards the introduction of obligations for institutions in adopting long-termist and sound investment management practices. We are of the view that the Articles discussed in this paper introduce regulatory measures for investment management practice, and the purpose and function of these Articles may not accord with the essential 'corporate governance' paradigm that Directive is framed in.

\footnotetext{
${ }^{1}$ Proposal for a Directive of the European Parliament and of the Council amending Directive 2007/36/EC as regards the encouragement of long long-term shareholder engagement and Directive 2013/34/EU as regards certain elements of the corporate governance statement ( $\operatorname{SWD}(2014) 126,127,128$ final) published 9 April 2014; Parliament amended version of 8 July 2015 at http://www.europarl.europa. eu/sides/getDoc.do?pubRef=-//EP//TEXT+TA+P8-TA-2015-0257+0+DOC+XML+V0//EN, Hereinafter known as 'Proposed Shareholders' Rights Directive'.

${ }^{2}$ Bank lending has shrunk in the post-crisis years although 2015 sees more recovery in bank lending, see 'Eurozone Credit Squeeze Ending, But Confidence Shaken by Greece', The Wall St Journal (29 April 2015) at http://www.wsj.com/articles/eurozone-credit-squeeze-ending-but-confidence-shaken-by-greece1430310018, see also ECB Lending Survey of April and July 2015, at https://www.ecb.europa.eu/ stats/money/surveys/lend/html/index.en.html.
} 


\section{European Shareholders' Rights Directive-provisions in focus}

In April 2014 the European Commission proposed several amendments to the Shareholders' Rights Directive including the introduction of an engagement policy for all institutions and a form of disclosure-based regulation of institutions' investment policies and strategies, their arrangements with asset managers, and the accountability of asset managers to institutions. ${ }^{3}$

Article $3 \mathrm{f}$ of the proposed Shareholder Rights Directive provides that Member States shall require institutional investors and asset managers to develop an engagement policy, which would state, inter alia, how institutional investors and asset managers intend to integrate shareholder engagement in their investment strategy, monitor their investee companies' performance, ${ }^{4}$ exercise their voting rights, use proxy advisors' services, and cooperate with other shareholders. Further Article $3 \mathrm{f}$ makes it mandatory that the engagement policy will address issues of management of conflicts of interest. Institutions are required to publicly disclose the engagement policy, how it is implemented and the results achieved. If they decide not to institute an engagement policy or to disclose the matters above, they need to provide a reasoned explanation for doing so.

Under the proposed Shareholder Rights Directive institutional investors should also annually disclose to the public their investment strategies and explain how such strategies are aligned with the duration of their liabilities and with the medium to long term performance of their assets. ${ }^{5}$ Additionally, the proposed Directive imposes disclosure obligations on asset managers, who must disclose on a half-yearly basis to their institutional clients how their investment strategies and policies intend to meet their clients' investment objectives and duration of liabilities, ${ }^{6}$ and on proxy voting advisors. $^{7}$

\subsection{Where the similarities lie between the articles in the Shareholder Rights Directive and the UK Stewardship Code}

The requirement in Article $3 \mathrm{f}$ which relates to the institution of an engagement policy on the part of institutional investors and asset managers, is similar to Principle 1 of the Stewardship Code, that requires UK institutions to develop a stewardship policy. The Stewardship Code however binds only voluntary signatories while the Directive is intended for application to all institutions in the EU.

The matters that may be stated in the engagement policy relate to how institutions:

(a) integrate shareholder engagement in their investment strategy;

\footnotetext{
${ }^{3}$ Proposed Shareholder Rights Directive, Arts. $3 \mathrm{f}$ to $3 \mathrm{~h}$.

${ }^{4}$ Including non-financial aspects and social and environmental risks.

${ }^{5}$ In particular, if institutions appoint asset managers, institutions must disclose as to how such arrangements would meet their objectives, their policies and strategies in evaluating asset managers and portfolio turnover, the duration of the appointment and how the agreed performance yardsticks and asset management charges and fees accord with their objectives. See Proposed Shareholder Rights Directive, Art. 3g.

${ }^{6}$ Proposed Shareholder Rights Directive, Art. 3h.

${ }^{7}$ Proposed Shareholder Rights Directive, Art. $3 i$.
} 
(b) monitor investee companies, including on their non-financial performance and the reduction of social and environmental risks;

(c) conduct dialogues with investee companies;

(d) exercise voting rights;

(e) use services provided by proxy advisors;

(f) cooperate with other shareholders;

(fa) to conduct dialogue and cooperate with other stakeholders of the investee companies.

Other than (e), (fa) ${ }^{8}$ and some aspects of (b) above, the matters in mandatory engagement policies are consonant with the Principles in the UK Stewardship Code. ${ }^{9}$ The Code is very much premised on the acceptance that an active corporate governance role for institutions will be aligned with their interest in the investment performance of their portfolio companies. ${ }^{10}$ Further, (b) is reflected in Principle 3 of the Code that requires institutions to monitor their investee companies. The acts of 'monitoring' are further developed in the Code, including being adequately informed about their portfolio companies. In this way, the Code may provide some input into how the Directive may be interpreted. (c) relates to Principle 4 of the Code which envisages escalation activities as part of active ownership where necessary, such escalation including holding dialogues with portfolio companies, such as with the Senior Independent Director of the Board.

(d) is reflected in Principle 6 of the Code which requires institutions to disclose their voting policies. One may argue that (d) goes further than its UK counterpart as it requires the exercise of voting rights to be part of engagement, and not merely the formulation of a voting policy and its due disclosure as is required under the Code. Finally, (f) is reflected in the Code's welcoming stance on collective engagement. Again, one may make a distinction between the two as (f) refers to co-operation and this may be wider than that captured in the Code's collective engagement paradigm. Collective engagement refers to joint activism by institutions in times of corporate stress or wider economic stress, and is thus premised upon the protection of collective economic interests in investment.

Further, Article $3 \mathrm{f}$ adopts a comply-or-explain approach i.e. that institutions should comply with the practice of developing an engagement policy as outlined in the Article, but if they choose not to they should explain how the lack of an engagement policy would still enable them to achieve their objectives. This is similar to the Code's comply-or-explain approach.

\footnotetext{
${ }^{8}$ Inserted as amendments by Parliament to the Commission's original proposal.

${ }^{9}$ Financial Reporting Council, UK Stewardship Code 2014 at https://www.frc.org.uk/Our-Work/CodesStandards/Corporate-governance/UK-Stewardship-Code.aspx.

${ }^{10}$ Although empirical literature is not so clear on the link between shareholder activism and performance, see Wahal [36]; Karpoff [23], although hedge fund activism and its unique features may constitute a different paradigm for investigation altogether, see Brav/Jiang/Partnoy/Thomas [6]; Becht/Franks/Grant/Wagner [3].
} 


\subsection{Where the Directive diverges from the UK Stewardship Code}

Adopting the signature comply-or-explain approach under the Code, and providing similar understandings of engagement in the Directive with stewardship under the Code, the Directive may be regarded as having borrowed from the pioneering efforts of the Code. This paper argues that the similarity is much more apparent than real. It is important to look at the substantive differences in order to appreciate the different nature of the obligations under the Directive and their underlying premises.

First, it is arguable that the proposed Directive demonstrates a normative expectation that shareholder engagement is part and parcel of investment management by institutions. Although an institution can clearly reject an engagement strategy and instead explain the irrelevance of shareholder engagement in its policy, the proposed Shareholder Rights Directive could be regarded as presuming in favour of the optimality of shareholder engagement as an investment management practice, and the onus is on institutions to explain why that is not the case. This approach goes some way towards hardening shareholder engagement norms although it falls short of imposing a 'duty' as such to engage. Under Article 3g, there is a duty to publicly disclose the implementation and achievement of any engagement on the part of institutions. Arguably the disclosure-based regulation compels that certain engagement conduct needs to be carried out in order for there to be sufficient matters to report. Although an institution can clearly reject an engagement strategy and instead explain the irrelevance of shareholder engagement in its policy, such an approach is likely to be regarded as the outlier and not the norm.

Next, Article $3 \mathrm{f}$ requires an engagement policy to account for how proxy advisors are used. The Code does not deal with the issue, as institutions are free to determine their investment management practices including their use of proxy advisers. As the paper will explain, the Code's stance is based very much on treating corporate governance as a private paradigm of relations between constituents that comprise the company, and the discharge of investment management practice is not a matter within the Financial Reporting Council's purview of corporate governance standards. The interest in proxy advisers is much more rooted in securities regulation, and in the UK, it would be the Financial Conduct Authority that may scrutinise this area of development. Article $3 \mathrm{f}$ reflects the Commission's interest in investment management, not only in its relationship to corporate governance, but as a regulable subject as such. This will be explained further below.

Article $3 \mathrm{f}$ was also amended by the European Parliament to shape the engagement policy towards non-financial performance and the reduction of social and environmental risks, and to compel institutions to engage with stakeholders in their engagement policies. This would likely reflect a broad-based public interest in making shareholders accountable for broader concerns in respect of companies' operations and to wider constituents in the exercise of their engagement powers. This is certainly contrary to the position in the UK. First, the UK regards companies and their management as being responsible for reporting on stakeholder relations and cor- 
porate responsibility footprints. ${ }^{11}$ Shareholders are regarded as 'enlightened' 12 and ought to be interested monitors of such issues, but requiring them to engage on these issues and treating these issues as being part and parcel of investment management practice would be a step too far compared to the UK approach. Further, the UK is still struggling with inhibitions in common law interpretations of the fiduciary duty for investment fund trustees ${ }^{13}$ in terms of being able to take on board non-financial considerations in investment performance. ${ }^{14} \mathrm{UK}$ company law also treats share ownership as giving rise to quasi-property rights whose exercise should not be arbitrarily curtailed, ${ }^{15}$ and hence the prescription of having to cooperate with stakeholders in engagement is likely to be regarded as contrary to shareholder rights and freedoms well-accepted in UK company law. ${ }^{16}$ It is arguable that the Code, being based on the company law framework in the UK, is premised on such a private proprietary conception of share ownership, and there is thus no conception of having to engage or negotiate with stakeholders in the freedom of use of property.

Public disclosure of the exercise of voting rights as required under Article $3 \mathrm{f}$ also seems to indicate the imposition of accountability on institutions beyond their investment management relationship with their beneficiaries. Further, Article $3 \mathrm{~g}$ specifies further public disclosure obligations on the part of institutions, in relation to their investment strategies, profile and duration of their liabilities and how such contributes to long-term corporate performance. Key elements of institutions' arrangements with their asset managers need to be disclosed. Article $3 \mathrm{~h}$ also deals with disclosure by asset managers to their institutional clients, in order to account for how asset managers meet their clients' needs in terms of investment horizon and maturity of liabilities. The European parliament has suggested amendments to require that a part of asset managers' disclosures be made public, with reference to:

(a) how investment decisions are made, in terms of considerations of long term corporate performance and non-financial performance;

(b) explaining the level of portfolio turnover;

(c) the management of actual or potential conflicts of interest in connection with engagement activities;

(d) the use or otherwise of proxy advisors for the purpose of engagement activities; and

(e) how their investment strategy and implementation contributes to the medium to long-term performance of the assets of the institutional investor.

One would have thought that the accountability parameters in investment management would revolve around institutions, their asset managers and other delegates, and

\footnotetext{
${ }^{11}$ Section 414A, UK Companies Act 2006.

${ }^{12}$ DTI, Company Law Reform; White Paper (March 2005) at http://webarchive.nationalarchives.gov.uk/+/ http:/www.dti.gov.uk/cld/WhitePaper.pdf; Keay [24].

${ }^{13}$ Cowan v Scargill [1985] 1 Ch 270; Harries and Others V. The Church Commissioners for England and Another [1992] WLR 1241; Thornton [35].

${ }^{14}$ Watchman/Anstee-Wedderburn/Shipway [37].

${ }^{15}$ Northern Counties Securities Ltd v Jackson \& Steeple Ltd [1974] 1 WLR 1133.

${ }^{16}$ Ibid.
} 
their beneficiaries. However, the key tenets of investment management and how they relate to institutions' long term liabilities and the impact on long term corporate performance are now regarded to be of interest for public disclosure. The possible public interest in these issues lies in the fact that the private wealth managed by institutions and asset managers are actually the long-term social wealth of the working citizenry, and the financialisation of household and pension savings cannot completely remove the public interest in these issues into the private contractual sphere. Further, as the performance of household and pension savings depends very much on the health of the corporate sector, the sustainability of the financial health of corporate sector also becomes an issue of public interest and not just of investment performance and numbers. This paper argues (see below shortly) that the public interest permeating these provisions of the proposed Directive is highly important and introduces a different character to the provisions on shareholder engagement from that embraced under the UK Code.

Finally, Article $3 \mathrm{i}$ imposes a duty on proxy advisory agencies to "ensure to the best of their ability that their research and voting recommendations are accurate and reliable, based on a thorough analysis of all the information that is available to them, and are developed in the sole interest of their clients'. These agencies are further subject to conduct standards in voluntary codes of conduct where they may be applicable. This paper suggests that as Article $3 \mathrm{i}$ puts emphasis on proxy agencies being able to ensure the reliability and accuracy of voting recommendations, apart from other standards of conduct that may be voluntarily applied, the imposition of a distinct legal duty on proxy advisory agencies seems contemplated. Such a duty could be capable of enforcement by their institutional or asset manager clients, or as will be suggested below, more appropriately framed as a regulatory duty accountable to a financial or securities regulator such as the FCA in the UK.

The potential framing of a duty owed by proxy advisory agencies to ensure reliable and accurate voting recommendations poses a number of challenges. This is because voting recommendations are likely to be regarded as 'opinions', and such are not normally actionable under the law of misrepresentation, ${ }^{17}$ although there is case law to suggest that an opinion that is not honestly held can amount to a misrepresentation. ${ }^{18}$ The standard introduced in Article $3 \mathrm{i}$ seems to indicate that proxy agencies may be liable for negligence, as proxy advisory agencies are asked to ensure 'to the best of their ability' that their voting recommendations are reliable and accurate. The adequacy of being informed is likely to form the cornerstone of such negligence liability.

It is questioned, however, why Article 3i should introduce negligence liability for proxy advisory agencies? Would not the general law in negligence deal with this issue, as proxy advisers likely owe a duty of care to the asset managers and their

\footnotetext{
${ }^{17}$ Bisset v Wilkinson [1927] AC 177; Ball v Banner [2000] EGCS 36, where property advisers' opinions as to the profitability of certain lettings are not held to be actionable misrepresentations.

${ }^{18}$ Smith $v$ Land and House Property Corporation (1884) LR 28 Ch D 7; Esso Petroleum Co Ltd v Mardon [1976] QB 801.
} 
institutional clients? ${ }^{19}$ Further, in this age of information abundance, what extent of research is needed on the part of proxy advisory agencies in order to discharge the standard of 'best of their ability'?

As will be discussed below, there is also the possibility that the duty framed in Article $3 \mathrm{i}$ is a regulatory duty, and hence introduces accountability to the securities regulator who can scrutinise whether the standard of 'to the best of their ability' is discharged. In such case the development of the regulatory standard may create a bifurcation from the general law of negligence, which is not inconceivable, given that the UK financial regulators have already introduced a separate conduct regime for many financial sector individuals apart from their general obligations in contract, trust, tort or company law. ${ }^{20}$ That said, it may be regarded as objectionable to impose a regulatory duty requiring accurate and reliable recommendations to be provided, as such a duty may easily be susceptible to enforcement with the benefit of hindsight. It is instructive to note that in the EU's regulation of credit rating agencies, ${ }^{21}$ credit rating agencies are not subject to a duty to ensure that their ratings are accurate or reliable as such, they are made subject to procedural duties that function as proxy signals to the quality of their credit ratings, such as having sound organisational and internal control arrangements, robust management of conflicts of interest, and compliance with certain standards of methodology prescribed in regulation. ${ }^{22}$ Further, credit rating agencies may be subject to civil enforcement for gross breach of regulatory duties causing loss, and not for 'inaccurate ratings' per se. . $^{23}$

Article $3 \mathrm{i}$ also requires proxy advisory agencies to make public disclosure of the following:

(a) the essential features of the methodologies and models they apply;

(b) the main information sources they use;

(c) whether and, if so, how they take national market, legal, regulatory and companyspecific conditions into account;

(d) the essential features of the research undertaken and voting policies applied for each market;

(e) whether and to what extent they have communication or dialogues with companies and their stakeholders,

(f) the policy regarding prevention and management of potential conflicts of interest;

(g) the total number and the qualifications of staff involved in the preparation of the voting recommendations;

(h) the total number of voting recommendations provided in the last year.

The requirements of public disclosure enable scrutiny into what proxy advisers have undertaken, 'to the best of their ability', in providing accurate and reliable voting

\footnotetext{
${ }^{19}$ The proximity required under a general duty of care in the law of negligence would likely be satisfied in the rather ascertainable scope of asset managers and institutions affected by proxy advisors' voting recommendations. Caparo Industries plc v Dickman [1990] UKHL 2.

${ }^{20}$ Approved Persons Regime or APER, in the FCA Handbook. See also Chiu [10].

${ }^{21}$ Regulation (EC) No 1060/2009 of the European Parliament and of the Council of 16 September 2009 on credit rating agencies.

${ }^{22}$ See Chiu [11]; Alcubilla/del Pozo [1]; Langohr/Langohr [27].

${ }^{23}$ Haar [22].
} 
recommendations. These support the suspicion raised in this paper that the duty in Article $3 \mathrm{i}$ could be framed as a regulatory duty, reflecting the public interest in the influence of proxy advisory agencies over institutions and asset managers who hold much financialised social wealth in their hands.

The examination of Articles $3 \mathrm{f}$ to $3 \mathrm{i}$ seems to show more divergence from the UK Stewardship Code than convergence or a natural ideological extension of the Code. This paper argues that the Articles are rooted in different objectives, and/or present ideological contradistinctions with what underlies the Stewardship Code.

\section{From corporate governance to financial/securities regulation}

The Commission explains ${ }^{24}$ that improving shareholder engagement is likely to address the issue of excessive short termism on the part of the asset management industry in managing institutional funds. In the Commission's view, short termism is not conducive for meaningful monitoring of corporate behaviour. Shareholders' shortterm demand for financial performance puts pressure on companies, compromising their long-term wealth creation potential. Further, short termism on the part of asset managers adversely affects ultimate returns for institutional beneficiaries. The Commission's concerns are rooted in public interest concerns regarding the viability of pension savings through investment. Hence, subjecting institutional investment management to standards and scrutiny is arguably a form of re-regulation, in order to ensure that the privatised and financialised form of social welfare provision may deliver public interest objectives in due course. ${ }^{25}$ In this regard, the gradual hardening of shareholder engagement norms serves the public interest purpose, and is a form regulation of investment management practices, although such norms are expressed as corporate governance standards. ${ }^{26}$

It may be counter-argued that as the proposed Shareholder Rights Directive is currently drafted, the Commission stays away from imposing an obligation on institutions to engage, and, hence, institutions remain free to determine the nature of engagement that works best for them. If this is the case, engagement as such, remains in the realm of soft law and the duty to develop an engagement policy may be regarded as a meta-regulatory measure ${ }^{27}$ where regulation sets out broad principles, the detailed implementation of which is left very much to the firm's discretion. It may be argued that such an approach is consistent with treating shareholder engagement as a choice in institutions' corporate governance roles, and is therefore not as prescribed as imagined above. However, as discussed above, there are assumed benchmarks of optimal behaviour in the Directive ie to engage, and much prescription that surrounds the nature of engagement and public disclosure. Hence, the provisions do not seem to be merely enabling or facilitative for shareholders to enhance their corporate governance positions. Rather, they seem to be more prescriptive as to how shareholders'

\footnotetext{
${ }^{24}$ Proposed Shareholder Rights Directive, at pp. 4, 5, 7 and 8.

${ }^{25}$ Broadbent/Palumbo/Woodman [7]; Polillo [33]; Erturk/Froud/Johal/Leaver/Williams [20].

${ }^{26}$ Policy underlying the Financial Services Action Plan 1999, Financial Services: Implementing the Framework for Financial Markets-Action Plan (1998) COM (1999) 232.

${ }^{27}$ Coglianese/Mendelson [16]; Parker [30, 31]; Scott [34].
} 
corporate governance positions should be framed in order to meet public interest objectives. The reference to engagement policies including stakeholder concerns, the reduction of social and environmental risks and cooperation with stakeholders reflect such position. This is a different approach from the UK Code which sees its engagement template as one that enhances shareholders' corporate governance positions in the agency-based paradigm of corporate law, if institutions choose to adopt it. Further, the provision on proxy advisers appears to be highly regulative in nature although it seems prima facie to give rise to civil obligations to their institutional and asset manager clients.

In sum, the position adopted by the Commission's proposed Directive contains many regulative and prescriptive elements within a wrapper of a comply-or-explain approach for institutions as regards shareholder engagement. This approach is inherently contradictory, especially given the expansion of the regulative aspects that Parliament has now introduced in the amended text. Regulating investment management intermediaries overtly is not out of step with the tenor of modern financial regulation. The buy-side in finance is disproportionately less regulated than the sell-side, and both sides give rise to issues of public concern such as financial stability and sustainability. ${ }^{28}$ There is increasing recognition that regulatory standards applied to both buy and sell-sides may need evening out from a functional perspective of the risks they generate. A possible explanation could be that the proposed Directive is under the purview of the Directorate for Justice and Consumers and not under the Internal Market Directorate which deals with financial regulation. Further, as regulatory scrutiny over the buy-side is only emerging at the international level, ${ }^{29}$ perhaps the Commission does not wish to engage in overt regulatory initiatives until international wisdom has matured in this area. The tentative nature of Articles $3 \mathrm{f}$ to $3 \mathrm{i}$ has made these provisions ambiguous in terms of their place in the intersection between the private agency-based paradigm in corporate governance and the more public interestoriented securities and financial regulation.

Nevertheless, it may be argued that the Shareholders' Rights Directive rightly deals with the 'publicisation' of corporate governance as the European perspective of corporate governance should not be confined to an Anglo-American one that emphasises the private and closed nature of corporate governance and intra-accountability. ${ }^{30}$ Such a perspective has arguably, artificially and unfairly shut stakeholders ${ }^{31}$ and the wider community out of discourse as to the normative objectives and accountabil-

\footnotetext{
${ }^{28}$ The buy-side in finance has consistently resisted regulation, for example, see the debates surrounding whether large asset managers should be subject to increased regulation in light of prudential concerns, FSB, FSB and IOSCO propose Assessment Methodologies for Identifying Non-Bank Non-Insurer Global Systemically Important Financial Institutions (4 March 2015), and the recent retreat of regulatory fervour in the wake of lobbying by asset managers, see 'Plans to label big fund managers 'systemic' in jeopardy', Financial Times (17 June 2015); 'Fund Managers to escape systemic label', Financial Times (14 July 2015).

${ }^{29}$ For example, FSB and Iosco, FSB and IOSCO publish Public Responses to the Second Consultative Document on NBNI G-SIFI Assessment Methodologies (12 June 2015) at http://www.financialstabilityboard. org/2015/06/fsb-and-iosco-publish-public-responses-to-the-second-consultative-document-on-nbni-g-sifiassessment-methodologies/.

${ }^{30}$ Easterbrook/Fischel [18]; Cheffins [9].

${ }^{31}$ Blair [5]; Blair/Stout [4]; Mayer [29]; Freeman [21].
} 
ity of the modern corporation. ${ }^{32}$ Hence, the Directive's approach to frame clearly shareholders' obligations and to introduce avenues of public accountability for them serves as an articulation of social expectations of institutional shareholder conduct. However, this view of the corporation may not be universally shared in Europe. ${ }^{33}$ This raises the question whether the harmonisation of such prescriptions for institutional shareholder conduct should be better carried out under the premises of securities or financial regulation, which will then open the way for securities regulators to subject investment management practices to scrutiny and enforcement by the relevant securities or financial regulator.

\subsection{Compatibility with UK corporate governance frameworks?}

Within the confines of this paper, the ideological debates relating to the corporate objective and corporate governance will not be canvassed, but this paper points out the conflict and contradistinctions that the 'publicisation' of corporate law will pose for UK corporate governance. In the UK, regulatory aspects of corporate governance have been introduced largely for the following reasons:

(a) mandatory rules necessary for ensuring a fair balance of power among the different constituents, such protecting minority shareholders and creditors;

(b) rules adopted by listing regimes in order to converge with reputable international standards or make the UK markets more attractive to both issuers and investors; and

(c) where transposition of European rules are required.

Company law provides for a regime of division of powers between shareholders and the Board so that certain exercises of power by the Board may be checked by the general meeting. ${ }^{34}$ Minority shareholders are especially protected via the litigation options of the derivative action ${ }^{35}$ and/or unfair prejudice petition, ${ }^{36}$ and where listed companies are concerned, they are further protected by the best practices of corporate governance ${ }^{37}$ adopted by the London Stock Exchange and the enhanced listing regime $^{38}$ introduced by the FCA to protect minority shareholders in block-holder controlled listed companies. Law and soft law have taken steps to the extent necessary to empower weaker groups in corporate governance where such weaknesses may be entrenched and exploited. They are targeted towards 'market failures' within the internal paradigm of the company, and aim to be as proportionate as possible in

\footnotetext{
${ }^{32}$ Mayer [29]; Keay [25]; Parkinson [32].

${ }^{33}$ For example, see Wymmersch [38]; Davies/Hopt [17].

${ }^{34}$ See for example, Part 10, chapter 4 of the UK Companies Act 2006, Arts. 3 and 4 of the Model Articles for Private and Public Companies Limited by Shares.

${ }^{35}$ S260-263, UK Companies Act 2006.

${ }^{36}$ S994, UK Companies Act 2006.

${ }^{37}$ UK Corporate Governance Code 2014, at https://www.frc.org.uk/Our-Work/Codes-Standards/Corporate -governance/UK-Corporate-Governance-Code.aspx.

${ }^{38}$ Listing Rules 6.1A, FCA Handbook, see discussion in Chiu/Barker [15].
} 
order not to disrupt the freedom of decision-making and organisation in the company, which is a private legal person. ${ }^{39}$

The soft law of corporate governance ${ }^{40}$ and stewardship ${ }^{41}$ are also purposed towards enhancing the attractiveness of London markets for issuers and investors in the global competition for listings and investments. ${ }^{42}$ They are seen as market-building measures reflecting the desires of the international investment community, introducing standardised best practices for Board composition and behaviour and the practices of shareholder engagement with their investee companies.

The UK's tendency to regulate corporate governance dynamics is very much bound up with a market-based view of the corporation-as an investible asset on the platform of internationally competitive securities markets, and as an engine of wealth creation driven largely by its capital providers and managers. Even reforms introduced in recent years relating to non-financial transparency ${ }^{43}$ and the obligation for directors to take into account stakeholders' concerns in long-term decision making ${ }^{44}$ revolve around changing market-based perspectives of the importance of 'environmental, social and governance' (ESG) concerns for the financial bottom-line of companies. ${ }^{45}$ The key market-based perspective of the corporation held in the UK, supported by company law and corporate governance frameworks that adopt a private paradigmatic approach, are at odds with the 'publicisation' of the corporation where corporate governance actors such as shareholders may need to conform to social expectations of their conduct, and where the characterisation of their rights may be less 'proprietary' in nature.

\section{Conclusion}

In the area of company law which is not subject to maximum harmonisation in the EU, it is queried to what extent Articles $3 \mathrm{f}$ to $3 \mathrm{i}$ of the proposed Shareholders' Rights Directive may sharpen the underlying ideological contests between the UK and the EU or among Member States of different leaning. In this light, we advocate that the public interest in investment management practices should be more sharply and overtly articulated as a basis for regulatory measures as part of securities and financial regulation. Hence, Articles $3 \mathrm{f}$ to $3 \mathrm{i}$ can then be properly reframed and debated as to whether a form of maximum harmonisation is required in the regulation of investment management practices in the EU. Such an approach can also pave the way for more thorough policy thinking in the realm of regulating investment management in its intermediation chains, including institutions, asset managers, proxy advisory agencies and other players in the chain. Upon these premises, the regulation or regulability of

\footnotetext{
${ }^{39}$ Armour/Whincop [2].

${ }^{40}$ UK Corporate Governance Code 2014, above.

${ }^{41}$ UK Stewardship Code 2014, above.

${ }^{42}$ La Porta/Lopez-de-Silanes/Shleifer [26].

${ }^{43}$ Such as the reforms to UK Companies Act 2006, s414A. See Chiu [12].

${ }^{44}$ S172, UK Companies Act 2006, see discussion in Laughrey/Keay/Cerioni [28].

${ }^{45}$ Chiu [13, 14]; Brown/Fraser [8].
} 
investment management practices including institutions' corporate governance role, can be more clearly and widely considered in the context of societal expectations and regulatory policy.

Acknowledgements The author is grateful for the opportunity to participate in the Annual Conference on European Company Law and Corporate Governance 2015, Trier, Germany, 17-18 September 2015, and the comments received on a related presentation. The author thanks Ms Vanessa Knapp OBE, Dr JeanPhilippe Robé and Professor Hans-Jürgen Hellwig for their insightful comments. All errors and omissions are mine.

Open Access This article is distributed under the terms of the Creative Commons Attribution 4.0 International License (http://creativecommons.org/licenses/by/4.0/), which permits unrestricted use, distribution, and reproduction in any medium, provided you give appropriate credit to the original author(s) and the source, provide a link to the Creative Commons license, and indicate if changes were made.

\section{References}

1. Alcubilla, R.G., del Pozo, J.R.: Credit Rating Agencies on the Watch List: Analysis of European Regulation. Oxford University Press, Oxford (2012)

2. Armour, J., Whincop, M.J.: The proprietary foundations of corporate law. Oxf. J. Leg. Stud. 27, 429 (2007)

3. Becht, M., Franks, J., Grant, J., Wagner, H.: The returns to hedge fund activism: an international study. ECGI Finance working paper No. 402, 2014

4. Blair, M.M., Stout, L.A.: A team production theory of corporate law Virginia. Law Rev. 85, 247 (1999)

5. Blair, M.M.: Ownership and Control: Rethinking Corporate Governance in the Twenty-First Century. Brookings Institute, Washington (1995)

6. Brav, A., Jiang, W., Partnoy, F., Thomas, R.: Hedge fund activism, corporate governance, and firm performance. J. Finance 63, 1729-1775 (2009)

7. Broadbent, J., Palumbo, M., Woodman, E.: The shift from defined benefit to defined contribution pension plans_-implications for asset allocation and risk management. BIS working paper, available at http://www.bis.org/publ/wgpapers/cgfs27broadbent3.pdf, 2006

8. Brown, J., Fraser, M.: Approaches and perspectives in social and environmental accounting: an overview of the conceptual landscape. Bus. Strategy Environ. 15, 103 (2006)

9. Cheffins, B.R.: Company Law: Theory, Structure and Operation. Oxford University Press, Oxford (1997)

10. Chiu, I.H.-Y.: Regulatory duties for directors in the financial services sector and directors. Duties in company law-bifurcation and interfaces. J. Bus. Law (2016, forthcoming)

11. Chiu, I.H.-Y.: Regulatory governance of credit rating agencies in the EU: the perils of pursuing the holy grail of rating accuracy. Eur. J. Risk Regul. 4, 209-226 (2013)

12. Chiu, I.H.-Y.: Reviving shareholder stewardship: critically examining the impact of corporate transparency reforms in the UK. Del. J. Corp. Law 38, 983 (2014)

13. Chiu, I.H.-Y.: The paradigms for mandatory non-financial disclosure: a conceptual analysis parts 1 . Co. Lawyer 27, 259 (2006)

14. Chiu, I.H.-Y.: The paradigms for mandatory non-financial disclosure: a conceptual analysis part 2. Co. Lawyer 27, 291 (2006)

15. Chiu, I.H.-Y., Barker, R.: Protecting minority shareholders in blockholder-controlled companiesevaluating the UK's enhanced listing regime in comparison with investor protection regimes in New York and Hong Kong. Cap. Mark. Law J. 10, 98 (2015)

16. Coglianese, C., Mendelson, E.: Meta-regulation and self-regulation. In: Baldwin, R., Cave, M., Lodge, M. (eds.) The Oxford Handbook of Regulation. Oxford University Press, Oxford (2010)

17. Davies, P., Hopt, K.J.: Boards in Europe: accountability and convergence. Am. J. Comp. Law 61, 301 (2013)

18. Easterbrook, F.H., Fischel, D.: The Economic Structure of Corporate Law. Harvard University Press, Cambridge (1996) 
19. Eilis, F.: Building an EU Securities Market. Cambridge University Press, Cambridge (2004)

20. Erturk, I., Froud, J., Johal, S., Leaver, A., Williams, K.: The democratization of finance? Promises, outcomes and conditions. Rev. Int. Polit. Econ. 14, 553 (2007)

21. Freeman, R.E.: A stakeholder theory of the modern corporation. In: Clarkson, M.B.E. (ed.) The Corporation and Its Stakeholders, p. 125. University of Toronto Press, Toronto (1998)

22. Haar, B.: Civil liability of credit rating agencies-regulatory all-or-nothing approaches between Immunity and over-deterrence. Available at http://ssrn.com/abstract=2198293, 2012

23. Karpoff, J.M.: The impact of shareholder activism in target companies: a survey of empirical findings. Available at http://papers.ssrn.com/sol3/papers.cfm?abstract_id=885365, Sep 2001

24. Keay, A.: Enlightened shareholder value, the reform of the duties of corporation directors and the corporate objective. Lloyds Marit. Commer. Law Q. 335 (2006)

25. Keay, A.: The Corporate Objective. Edward Elgar, Cheltenham (2011)

26. La Porta, R., Lopez-de-Silanes, F., Shleifer, A.: What works in securities laws? J. Finance 71, 1 (2006)

27. Langohr, H., Langohr, P.: The Rating Agencies and Their Credit Ratings: What They Are, How They Work and Why They Are Relevant. Wiley, Chichester (2010)

28. Laughrey, J., Keay, A., Cerioni, L.: Legal practitioners, enlightened shareholder value and the shaping of corporate governance. J. Corp. Law Stud. 8, 79 (2008)

29. Mayer, C.: Firm Commitment. Oxford University Press, Oxford (2013)

30. Parker, C., Meta-Regulation: Legal accountability for corporate social responsibility. Available at http://papers.ssrn.com/sol3/papers.cfm?abstract_id=942157, 2006

31. Parker, C.: The Open Corporation. Cambridge University Press, Cambridge (2002)

32. Parkinson, J.E.: Corporate Power and Responsibility. Clarendon Press, Oxford (1993)

33. Polillo, S.: Wildcats in banking fields: the politics of financial inclusion. Theory Soc. 40, 347 (2011)

34. Scott, C.: Regulating everything: from mega- to meta-regulation. Administration 60, 61 (2012)

35. Thornton, R.: Ethical investments: a case of disjointed thinking. Camb. Law J. 67, 396 (2008)

36. Wahal, S.: Pension fund activism and firm performance. J. Financ. Quant. Anal. 31, 1 (1996)

37. Watchman, P.Q., Anstee-Wedderburn, J., Shipway, L.: Fiduciary duties in the 21st century: a UK perspective. Trust Law Int. 19, 127 (2005)

38. Wymmersch, E.: Convergence or divergence in corporate governance patterns in western Europe. In: McCahery, J. (ed.) Corporate Governance Regimes: Convergence and Diversity. Oxford University Press, Oxford (2002) 